\title{
Natural reduction of Ukraine's population: Regional dimensions of the national threat
}

\author{
MyrosLav DNISTRIANSKYI ${ }^{1}$, József MOLNÁR² and Iryna CHAIKA ${ }^{3}$
}

\begin{abstract}
A significant decline in Ukraine's population is mainly due to its natural decrease, which began in the 1970s and 1980s in the rural areas and had been determined by the objective trends in demographic transition, the inertia effect of the demographic losses in the past and the social policy of the political regime at that time. Likewise, the social and economic crisis of the 1990s deepened the depopulation processes. In the present research, correlation analysis demonstrated a relationship between the current dimensions of natural population decline and a number of socio-demographic factors (proportion of the rural population, mean age of the population, divorce rate and the mean age at first marriage). In recent years, the effects of the demographic crisis have been particularly acute in North-eastern and Central Ukraine, due to the deepening disproportions in the age and sex structures of the population. However, in the capital of Ukraine, Kyiv, and in some western regions, the natural decrease in population is less acute because of more balanced social and demographic indicators. Although religious and ethnic factors contribute to some extent to greater natural population growth, especially in the western and south-western regions, their impact on the processes of population reproduction in Ukraine is generally not significant. To sum up, in order to stop natural population decline in Ukraine, it is important to ensure more favourable conditions for demographic development in the economic, social, informational and cultural spheres of society. Furthermore, in areas of acute demographic crisis, it is important to raise the issue of rural reconstruction involving a variety of organisational and economic mechanisms.
\end{abstract}

Keywords: natural population decline, depopulation, demographic transition, demographic crisis, age structure, birth rate, death rate, Ukraine

Received July 2021, accepted October 2021

\section{Introduction}

The ongoing population decline since the beginning of the $21^{\text {st }}$ century is characteristic of all the post-Soviet states of Central and Eastern Europe (SKrYZHevsKa, Y. and KarácsONYI, D. 2012). Some authors even consider the process of depopulation that developed countries have experienced in recent decades a global direction in the demographic development of society, the so-called Second Demographic Tran- sition (SDT) (VAN DE KAA, D.J. 2002). However, while in most Central and Eastern European countries population decline has been primarily attributed to the negative balance of external migration, the main factor in the significant reduction of the demographic potential of Ukraine and most of its regions has been depopulation. The population decline is, thus, due to a negative natural increase, rate which is so substantial that it already poses a national threat.

\footnotetext{
${ }^{1}$ Department of Geography of Ukraine, Faculty of Geography, Ivan Franko National University of Lviv. 79000 Lviv, Doroshenka St. 41, Ukraine. E-mail: m_dnister@ukr.net

2 Department of Geography and Tourism, Ferenc Rakoczi II Transcarpathian Hungarian College of Higher Education. 90202 Berehove, Kossuth Sqr. 6., Ukraine. E-mail: molnar.jozsef@kmf.org.ua

${ }^{3}$ Department of Economic and Social Geography, Faculty of Geography, Ivan Franko National University of Lviv. 79000 Lviv, Doroshenka St. 41, Ukraine. E-mail: i.dnistrjanska@gmail.com
} 
According to official statistical bodies, from 1993, when the first decrease in the population of Ukraine was recorded, to 2020 the population of Ukraine decreased by 10.342 million people $(19.8 \%)$. In the same period, the loss of population due to a negative migration balance was 1.221 million people, i.e. about 11.8 percent of the total population decline. Meanwhile, natural decrease resulted in a decline of 9.121 million between 1993 and 2020, i.e. an average of more than 330,000 people annually. As a result of its declining population, Ukraine dropped in the World Population Ranking from the $22^{\text {nd }}$ place at the beginning of the 1990 s to the current $35^{\text {th }}$ place.

However, the actual migration losses are larger and therefore the general population demographic losses also, because a significant part of Ukrainian migrant workers while still retaining Ukrainian citizenship, became permanent residents in the countries that had provided employment to them. Such a critical demographic situation poses a real nationwide threat of an increase in negative socio-political and economic consequences, such as ageing, declining human resources, a growing economic burden on working age people, declining rural settlements and their gradual disappearance in some regions.

Since depopulation in Ukraine is significantly differentiated by regions, and given the general negative trends, the demographic situation is particularly critical in some areas whereas in others it is more favourable due to different natural, historical and geographical, socio-economic and ethno-geographical conditions. Therefore, determining the role of various factors in natural population decline in Ukraine is first of all an important cognitive problem and an opportunity to understand the mechanisms of demographic development in the post-Soviet space in general. Nonetheless, identifying the causes, consequences and regional differences of depopulation in Ukraine may serve as an information basis for a demographic policy aimed at addressing various impacts of the demographic crisis and balancing regional demographic trends.

\section{Scientific considerations of population decline}

The analysis of the demographic situation in Ukraine should be considered in the context of demographic development in other countries as well as with regard to different methodological approaches to their assessment. In particular, in order to understand the problems of population ageing in Ukraine, it is important to analyse the processes of age structure change of the US population in the context of social problems which was dealt with in the studies of Brown, D.L. and GLAsGow, N. (2012) and Kulcsár, L.J. (2019). In these works, the authors emphasise the relationship between a low employment rate, social infrastructure and population ageing. Likewise, Champion, T.G. and Shepherd, J. (2006) consider the objectivity of the preconditions for the decrease of the rural population in Great Britain. Furthermore, the dependence of age structure change in the context of various aspects of employment is revealed in the works of STOCKDALE, E. (2011). In addition, he draws attention to some positive aspects of population ageing, such as increasing social activity in such an environment. However, the most heated discussions about depopulation are being conducted among Russian demographers, since a number of experts e.g. Vishnevskiı, A.G. (2005), etc. - reasonably emphasise the processes of natural population decline in view of industrialisation and urbanisation. Other authors (e.g. Levashov, V.I. and Staroverov, V.I. 2000), however, see the causes of population decline exclusively in the contradictions of the social, political and economic transformations that have taken place in Russia over the past thirty years. This is, however, a biased approach. At the same time, Polish demographic analysis focuses on the impact of the migration of Polish youth on depopulation in Poland and its geography, primarily in rural areas, (BAŃSKI, J. and WesoŁowska, M. 2020).

The demographic crisis in Ukraine has caused a significant resonance, primarily among Ukrainian academics and scientists. 
This is especially true of the scholarly works of academic researchers such as RoHozHIN, O.H. (2004), Terets, V.M. (2009), SHVydKa, H.Y. and Shevchuk, P.Y. (2009), Gladun, O.M. (2013), Libanova, E.M. (2014), and others who emphasise the social and economic aspects of the demographic crisis. A geographical analysis of the demographic processes underlying the crisis of population reproduction especially in relation to its ageing and increasing mortality, presented by regions of Ukraine, was carried out by Melnyk, I. (2012), Yavorska, V.V. (2015), and Yeliseyeva, L. (2015). Further, Dzhaman, V.O. (1998), Baranovskyi, M. (2009), Sehida, K. (2009), Hudzelyak, I.I. (2011), Poruchynska, I. (2014), and others carried out research in individual regions. As most of these studies were conducted at the level of individual regions, it was not possible to fully reproduce the problem of depopulation on a nationwide scale.

The seriousness of the demographic crisis in Ukraine has also been highlighted in the publications of foreign authors (e.g. Rowland, R.H. 2004). However, few publications in English devoted to rural depopulation in Ukraine have been published. The study by SKrYZhevsKa, Y. and KarácsonYI, D. (2012) analysed major trends and regional variations in Ukraine's rural population decline, as well as the problems of rural areas that have been affected by the demographic crisis. In addition, it attempted to provide recommendations that would help revitalise rural areas. Still, the available academic literature does not make it possible to create a holistic image of the formation and reproduction processes of natural population decline in Ukraine, as a number of issues in understanding the problem have remained unresolved. These are, in particular: 1) lack of conceptual explanation of regional demogeographic differences, including the emergence of negative demographic trends in the north-eastern regions of Ukraine; 2) not all socio-cultural mechanisms of depopulation have been investigated, no interdependence of demographic and social indicators has been revealed; 3) ethno-demographic and some territorial and political aspects of the problem have not been covered.

Given the lack of knowledge in the field of natural population decline in Ukraine, the purpose of this study is to identify trends in the genesis and evolution of this demographic phenomenon, determine the main mechanisms of its reproduction in the context of modern socio-economic conditions and identify practical opportunities to thwart some negative demographic trends. In order to accomplish the set goals, the following tasks shall be addressed: 1 ) determine the historical and geographical trends in the reproduction processes for the population of Ukraine over the past 50 years; 2 ) identify modern socio-demographic relationships and interdependencies in the process of natural reduction, their socio-political significance, as well as allocating areas of demographic disaster and areas with a relatively favourable demographic situation; 3) substantiating perspective variants of regional policy in the demographic sphere, which would contribute to a certain improvement of the demographic situation.

\section{Conceptual and methodological frameworks}

The present study is based on the theory of demographic transition that emphasises the objectivity of moving away from the traditions of a large family and natural population decline in the process of industrialisation and urbanisation. A working hypothesis of the study is also the statement that the emergence and spread of depopulation in Ukraine within the command-administrative system was influenced by some features of the then state policy, whereas in transition economies the process of deepening population decline occurred under the influence of socio-economic uncertainty. Based on these methodological principles, the following sequence of research steps was executed: 1 ) in order to identify the origins of depopulation, a historical and geographical analysis of natural growth decline 
in the regions of Ukraine in the second half of the twentieth century was carried out; 2) a structural and functional analysis of the current demographic situation in Ukraine was conducted using correlation analysis to determine the system of relationships in modern socio-demographic relations; 3 ) the areas of critical demographic situation at mid-level administrative units were identified by means of the cartographic method; 4) using a promising approach, proposals to halt the processes of natural population decrease in the context of socio-economic development in Ukraine were substantiated.

Pearson's parametric coefficient of correlation was used to identify the relationships between natural increase values and other social indicators according to paragraph 2. The precondition for its use has been the normal distribution of variables. The Kolmogorov-Smirnov tests demonstrate no difference from normal at 95 percent confidence level in the majority of these indicators, except for marriage, GRP per capita and migration balance (but at a 99\% confidence level their distribution does not differ from normal either). Consequently, the use of Pearson's correlation coefficient is valid.

Correlation analysis found significant 95 percent direct and inverse relationships between natural increase and various socioeconomic indicators. The detected correlation may be an indicator of the existing causal relationships between the phenomena, though it may indicate dependence of the phenomena under analysis on some common factor. To avoid redundancy (repeated consideration of the same factors due to the interdependence of factors), a multiple regression analysis was performed using the SPSS program. The influence of factors such as, mean age of the population, number of marriages (per 1,000 people), mean age at first marriage (for both men and women respectively), rate of divorces, proportion of the rural population, proportion of females in total population, proportion of Ukrainians and Russians in total population, percentage of working-age women (1564 years) in total female population on birth and death rates as well as on natural increase was analysed. In addition, the impact of the number of arrivals, departures and migration balance (per 10,000 people), the number of students of higher education institutions (per 1,000 people), gross regional product (GRP) per capita, average monthly income of household members and average monthly household expenditures were also considered. Data of the regions of Ukraine and the city of Kyiv for the year 2019, except for the fully or partially occupied Crimea, Donetsk and Luhansk regions, a total of 23 administrative units were used for the analysis.

\section{Main results of the research}

Europe's most developed countries abandoned the traditionally large family model before World War II. This process was associated with cultural and attitudinal changes in the midst of rapid industrial development, urbanisation and education of the population. Such trends led, on the one hand, to a sharp decline in birth rates and to a reduction in mortality on the other. Following the post-WW2 baby boom, the processes of declining birth rates resumed, laying the groundwork for the upcoming fall in reproduction in these countries.

\section{When, where and why did depopulation begin in Ukraine?}

Ukraine's demographic development in the early second half of the $20^{\text {th }}$ century generally corresponded to European trends with regard to declining natural growth. Yet, it had its differences, which were due to the greater influence of traditional views on the family and the peculiarities of the socio-demographic policy of the then USSR. Thus, it can be stated that based on a gradual and steady decrease in birth rates (from 20.5\% in 1960 to $15.1 \%$ in 1975 ) and natural increase (from $13.6 \%$ in 1960 to $5.1 \%$ in 1975) (The population of USSR 1988. Statistical Yearbook 1989), Ukraine underwent, like other Euro- 
pean countries, a new stage of demographic transition toward a shrinking reproduction.

The ongoing processes in Ukraine had, nevertheless, specific features related to the demographic losses of the past and the then state policy. In particular, state policy promoted artificial urbanisation and a negative ideological attitude to rural areas, which had been seen as a source of socio-political conservatism. As a result, most rural settlements were declared unpromising (Gladun, O.M. 2013). ShvydKa, H.Y. and SHevchuк, P.Y. (2009), in their analysis of the influence of previous age cohorts on the sex and age structure of the population, determined the significant changes in the population structure of Ukraine which had been caused by the two world wars, forced collectivisation and the famines of 1932-1933 and 1946-1947. Similarly, the historian Kovpak, L.V. (2010) states that, as a result of the expanding and resettlement campaign forcibly carried out by the state, out of the 58.5 thousand farms in Ukraine in the 1960s, only 8.4 thousand survived. Therefore, a retrospective reflection on the annual indicators of natural increase in Ukraine's rural and urban areas testifies that it was in rural areas where the process of depopulation began in the 1970s and 1980s. This is evidenced by the fact that the rate of natural increase in rural areas of Ukraine has been negative since 1979 (The population of USSR 1988. Statistical Yearbook 1989). According to Karácsonyi, D. et al. (2014), the 1960s and 1970s witnessed the mass resettlement of the rural population in cities, which resulted in an annual increase of half a million in the population of the block of flats-cities ("Khrushchovkacities"). The rural areas experienced a fall in population, first caused by emigration, then - from the 1970s onwards - by the low natural increase rate of an ageing society.

In regional terms, depopulation processes in rural areas began in North-eastern Ukraine (Chernihiv, Sumy, Poltava regions), in territories located in the area of influence of the largest cities of the country - Kyiv and Kharkiv. The economic opportunities and relatively well-developed infrastructure of these cities attracted the young rural population, which had been dissatisfied with the socio-economic living conditions in the then Ukrainian village. Meanwhile, mass migrations of young people from these regions to cities caused a steady ageing of the rural population and a decrease in natural growth. This first occurred in the villages of Chernihiv, Sumy, Poltava regions and later in the neighbouring regions. Against that backdrop in 1980, when the average natural growth rate of the rural population in Ukraine was -0.7 per thousand, in the Chernihiv region it dropped to -7.6 per thousand, in Sumy to -7.5 per thousand, and in Poltava to -7.3 per thousand (The national economy of the Ukrainian SSR in 1990, 1991). Thus, the excessive focus of economic development policy on large urban centres, in combination with unfavourable social and living conditions of rural areas caused large disparities in the age structure of residents of large cities and rural areas in the north-eastern and central regions. The decline in natural growth rates in these regions was influenced by the indirect demographic losses of rural areas stemming from the 1932-1933 famine (Levchuк, N.M. et al. 2015) as well as by the state policy, which encouraged the younger population to leave for the eastern regions of the former USSR to raise their economy. Meanwhile, migrants from rural areas faced housing and other social problems in the major cities, so under the pressure of domestic problems and urban lifestyles, they switched to the "one family - one child" model. As a result, in rural areas, where the traditions of the large family had been retained, the age structure did not promote simple or extended reproduction, whilst in large cities a sociopsychological transition to narrow reproduction was already underway (DNISTRIANSKYI, M.S. 2012).

In consequence of the negative demographic transformations of the 1970s, by 1980 the coefficient of natural growth of the whole population (both rural and urban) had become negative in five regions (Vinnytsia, Poltava, Sumy, Cherkasy, Chernihiv), to which the Kirovohrad region was added in 1985 (The national economy of the Ukrainian SSR in 
1990, 1991). Later on, the demographic transition spread to all regions, albeit to varying degrees. Therefore, in general, the natural increase in the population of Ukraine was steadily declining. In 1990, depopulation spread to almost half of the regions of the country, and the total rate of natural population growth in Ukraine became minimal (only $0.6 \%$ o). Such trends in demographic development resulted in a natural decrease in population, which occurred in 1991, when the natural growth rate became negative $(-0.8 \%)$. This was mainly due to the growth of depopulation processes in villages, because in urban settlements in 1991, the natural increase remained positive (1.1\%o) (State Statistics Service of Ukraine 2021). However, by 1992, the natural decline had already taken place in the urban environment due to new approaches to family modelling in the process of the demographic transition. Since then, Ukraine's depopulation has continued to this day, though in some western oblasts (regions), given the larger proportion of the rural population, its optimal age structure and the preservation of large family traditions, the natural growth rate kept positive for a long time. In particular, during the 1990s the natural growth rate remained positive in the Zakarpattya and Rivne regions. However, at the beginning of the $21^{\text {st }}$ century, depopulation expanded to most of the western regions. Thus, since then, Ukraine has entered a phase of acute demographic crisis.

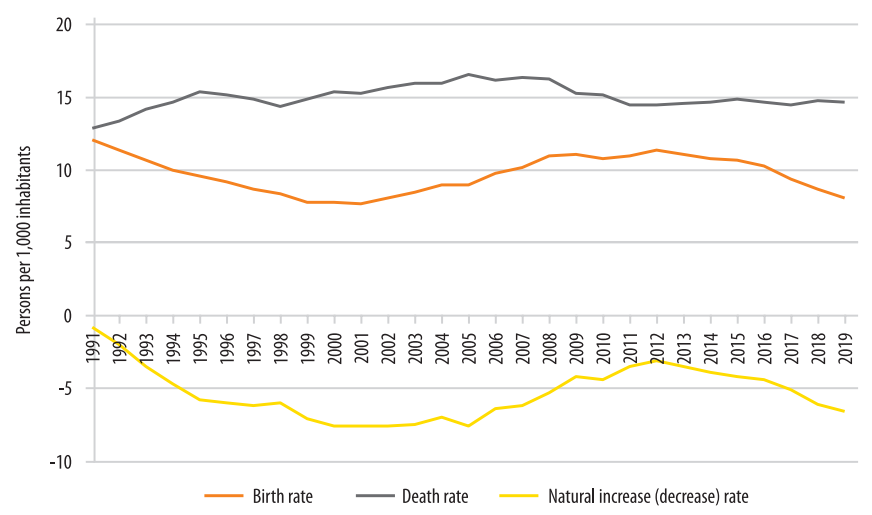

Fig. 1. Dynamics of the natural movement of the population of Ukraine
The term "demographic crisis" was first used in Ukraine in 1985 by the Ukrainian demographer Steshenko, V. (SKryzhevska, Y. and KarácsonYI, D. 2012).

Accordingly, the trends leading to a natural population decline, which had appeared in the 1980s, deepened as a result of the economic crisis of the 1990s. Certain economic problems, especially job losses and forced travel abroad to earn money, deepened social problems at the family level, which in turn, led to a sharp increase in the number of divorces and a significant decline in marriages. Thus, whereas in 1991 there were 9.5 marriages and 3.9 divorces per thousand people, in 2000 the number of marriages dropped to 5.6 and the number of divorces increased to 4.0 per thousand (State Statistics Service of Ukraine 2021). However, it is difficult to identify a direct relationship between declining natural growth and economic development, as economic indicators in the western regions with a relatively favourable demographic situation were worse than in regions where unfavourable demographic processes (declining birth rates and rising mortality, ageing population, growing demographic burden on the working population, etc.) were particularly noticeable. It seems, therefore, that the natural population decline was due mostly to the inertia of demographic processes of the pre-war and post-war periods. A secondary factor was the combined effect of a number of socio-demographic factors, primarily deepening disparities in sex-age and socio-age structures of the population in the process of urbanisation, socio-psychological changes to marriages and divorces, which had violated the mechanisms of reproduction in general.

From 2006 to 2012, there was a generally positive tendency to an increase in the natural growth rate (in 2005 this indicator was $-7.6 \%$, in 2012 only $-3.1 \%$ ) (Figure 1). This increase in natural growth occurred 
due to a slight rise in birth rates (in 2005 the birth rate was $9.0 \%$, in 2012 it amounted to $11.4 \%$ o). This growth is associated, as evidenced by the study of HudzELYAK, I.I. (2011), with an intensification of the demographic policy of the state, manifested in an increase in financial support in case of childbirth, and a slight decrease in mortality, mainly only among the urban population. At the same time, there were some positive socio-cultural changes in approaches to family planning at the level of individual families, in particular, withdrawal from the principle of "one family - one child". This was evidenced by a gradual increase in the total fertility rate per woman (2005: 1.213, 2013: 1.506). At the same time, since the beginning of the $21^{\text {st }}$ century there has been a steady increase in the average age of men and women marrying for the first time: from 25.2 years for men and 22.0 years for women in 2000 to 26.3 years for men and 23.3 for women in 2013 (State Statistics Service of Ukraine 2021). In fact, however, since 2014, all demographic indicators in Ukraine have steadily deteriorated due to the new social instability caused by military actions that have resulted in the violation of the territorial and political integrity of Ukraine (Yavorska, V.V. 2015). Given the socio-political instability, the demographic situation in areas close to the front line has deteriorated sharply.

According to official information from statistical bodies, since 2005 the migration balance in Ukraine has been positive and this trend continues to this day. In particular, during 2019, the population of Ukraine as a result of external migration increased by 21,512 people (State Statistics Service of Ukraine 2021). However, in fact, the external migration situation is not optimistic at all because of the growing numbers of Ukrainian citizens moving abroad to study and work between 2014 and 2019. According to some estimates, from 7 million to 9 million people were involved in the foreign migration process at that time every year, negatively affecting all aspects of population reproduction in Ukraine (www.slovoidilo.ua 2019).
What national and regional trends in demographic development are characteristic of modern Ukraine?

In present-day Ukraine, the natural population decline continues (in 2019, the natural growth rate was $-6.6 \%$ ) as a result of decreasing birth rates and high mortality rates, including infants under 1 year. The population has been ageing rapidly. According to YELISEEVA, L. (2015), this trend poses "a serious challenge to the financial and economic system, especially in the field of public finances, the pension system and the labour market". The gender structure of Ukrainian society also remains unbalanced, especially in the eastern and central regions, where there are many more females because of the ageing society. Equally noticeable is the differentiation of the regions of Ukraine by all demographic parameters, in particular by birth, death and natural increase rates (Figures 2-4). The cartographic representation of these indicators reveals a certain correspondence of the main areas with the highest mortality and the lowest birth rate and vice versa, which indicates primarily the role of basic social, gender and age population parameters.

Both in terms of fertility and mortality, crisis situations can be observed in the northeastern regions, where due to all mechanisms of population reproduction, the trend towards depopulation has only deepened: natural growth rates are the lowest (from 0 to $8 \%$ ) and mortality rates the highest (from $18 \%$ o to more than $22 \%$ ) there. As a result, in certain places natural reduction has reached -20 per thousand and less (see Figures 2-4). In recent years, the central and some eastern regions have come close to these crisis regions by the main demographic dynamics, thus, testifying to the interconnectedness of a number of socio-demographic factors, which has also been confirmed by the calculated correlation coefficients (Figure 5). Thus, correlation analysis reveals a close inverse relationship between natural increase, on the one hand, and mean age as well as the predominance of women over men (correlation coefficients $(-0.91)$ and $(-0.80)$, respectively) on the other. 


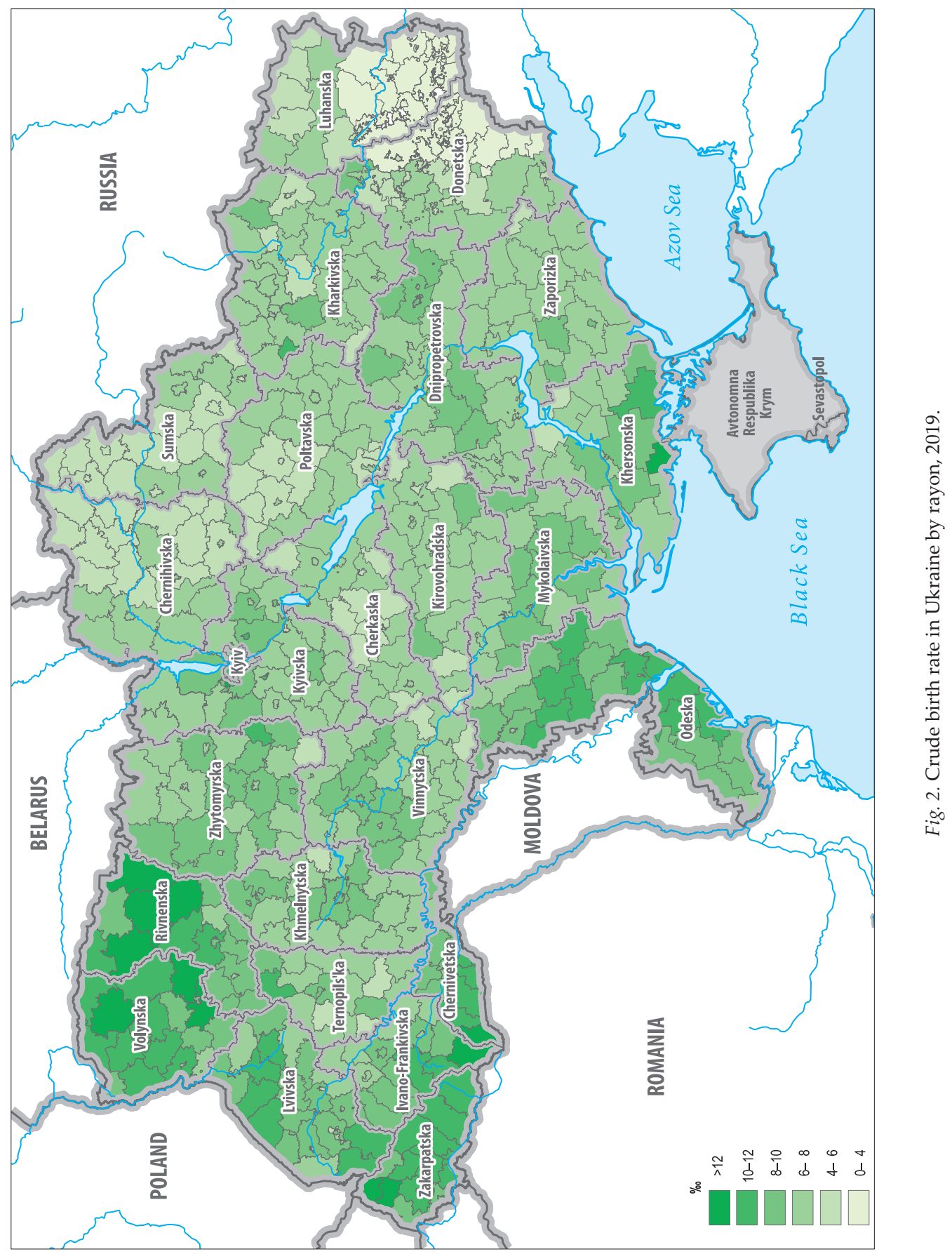




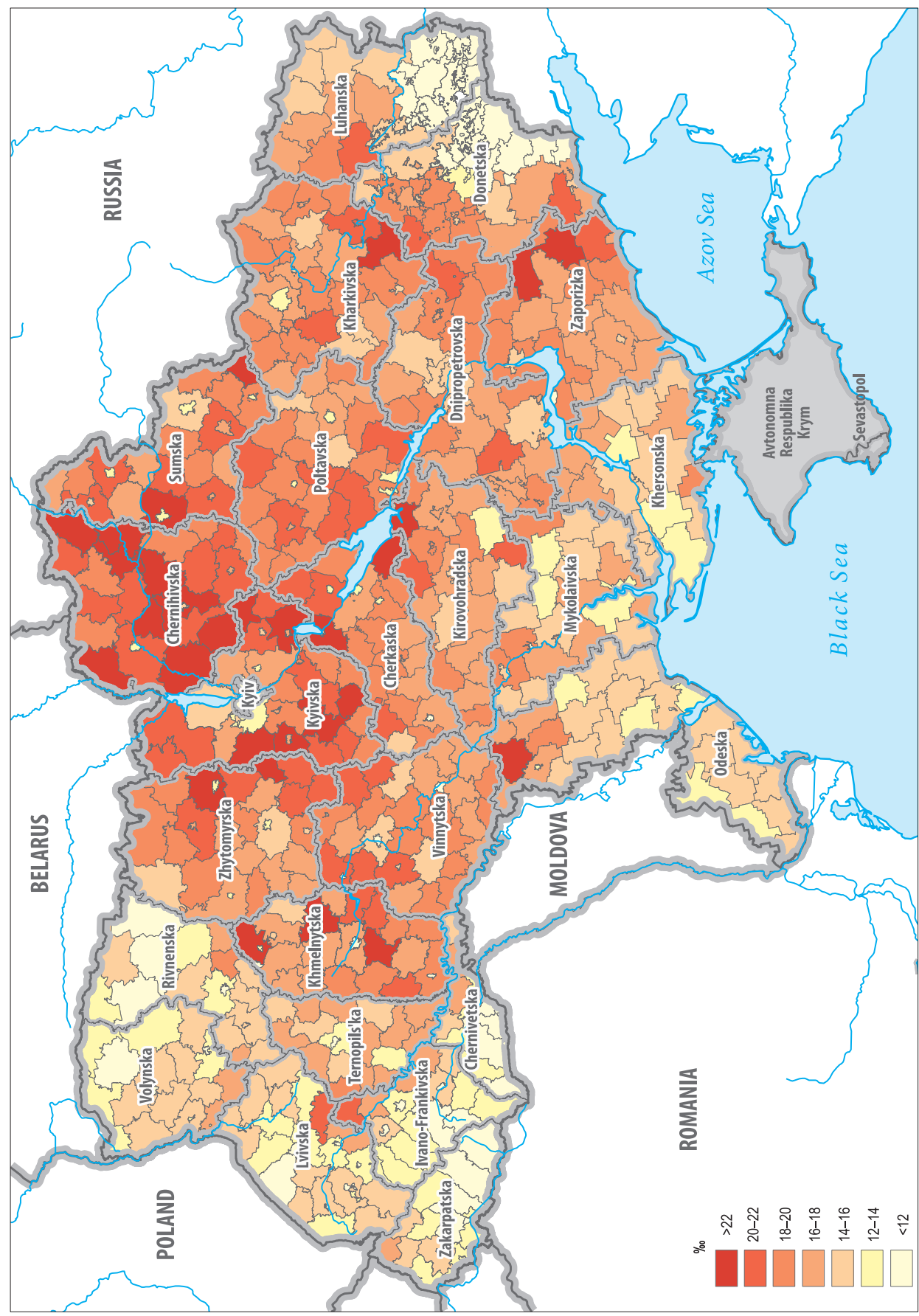

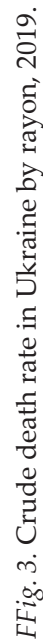




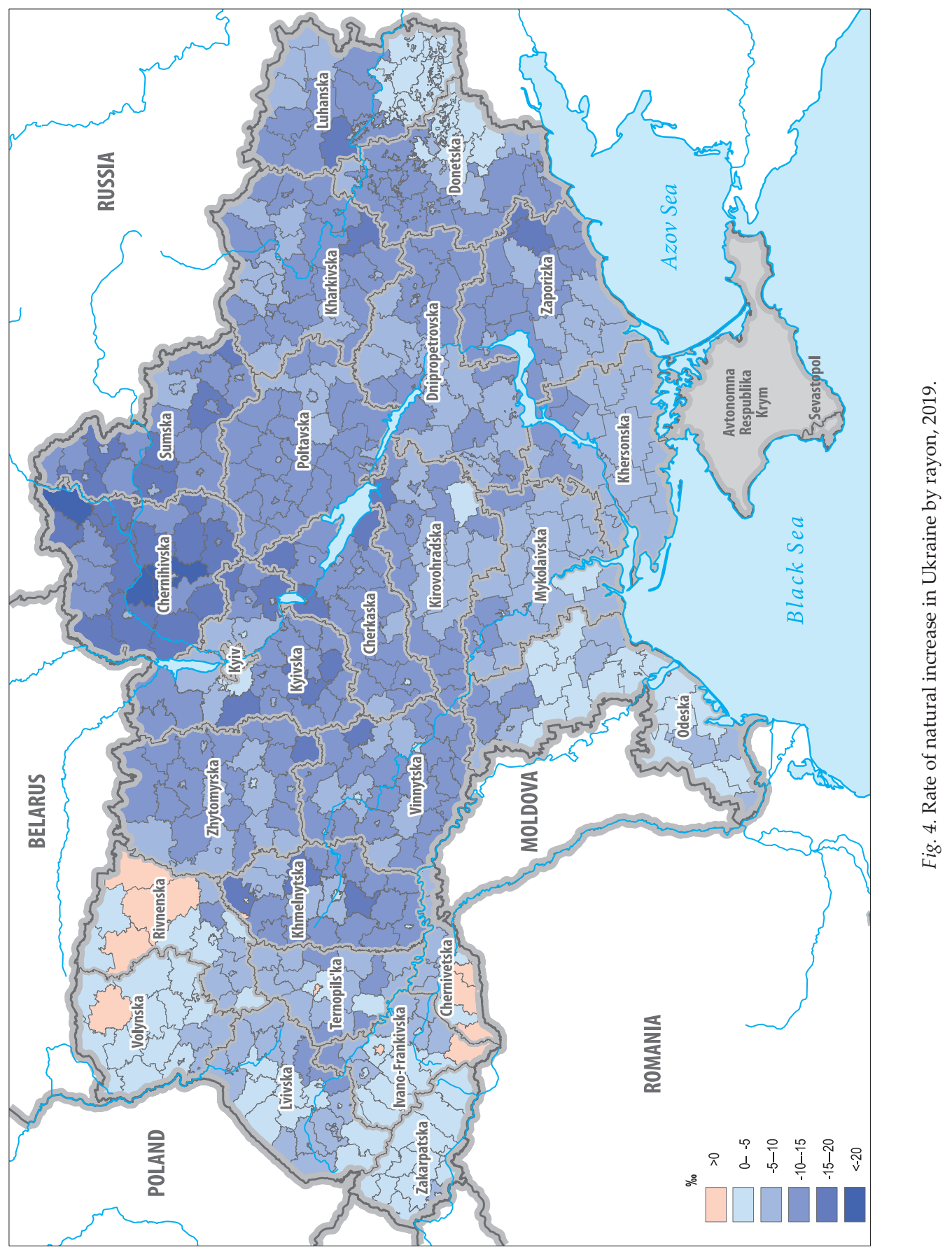



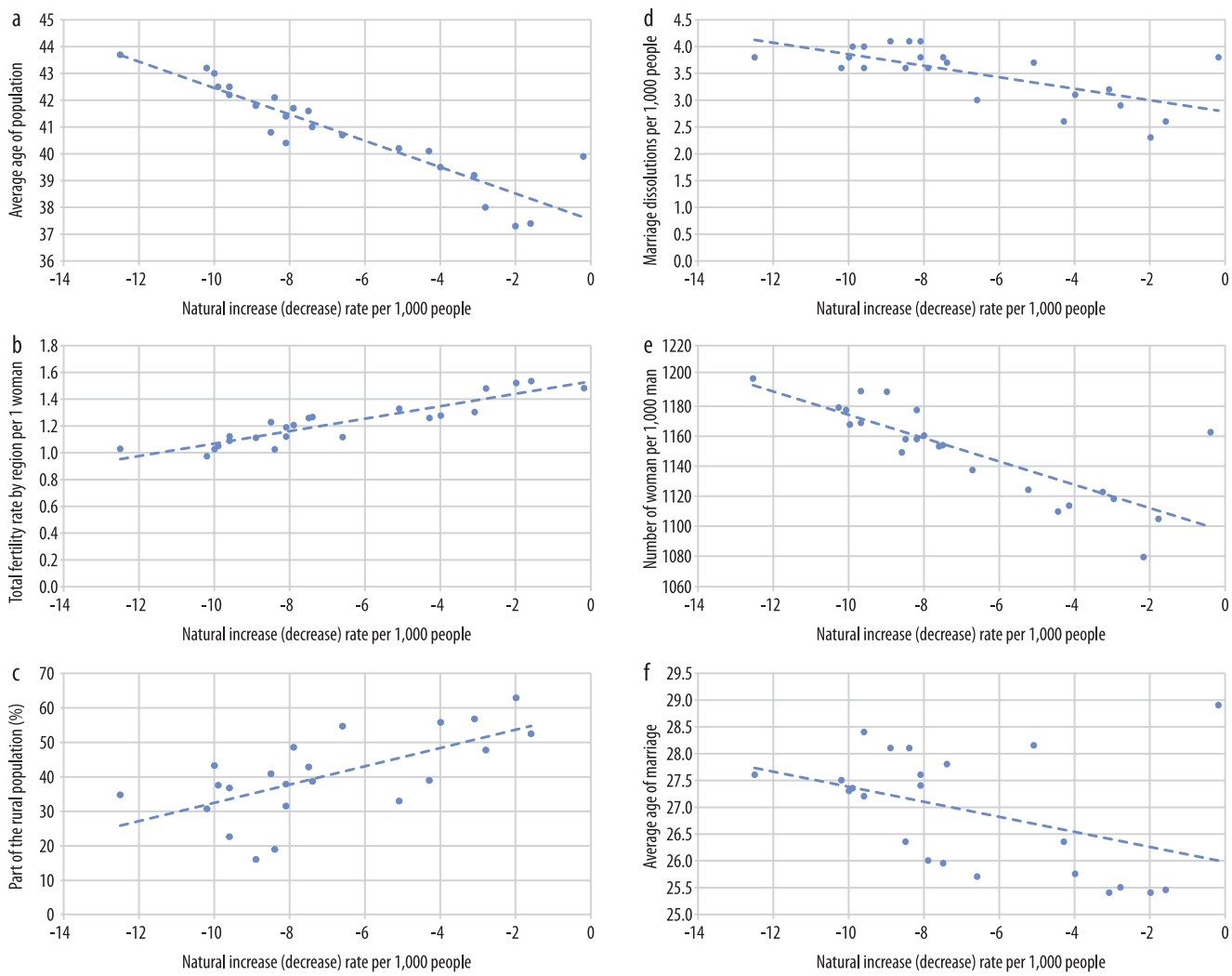

Fig. 5. Graphs of correlations of: $\mathrm{a}=$ natural growth rate and mean age of the population $(-0.91) ; \mathrm{b}=$ natural growth rate and fertility rate $(0.91) ; \mathrm{c}=$ natural growth rate and proportion of the rural population $(0.65)$; $\mathrm{d}=$ natural increase and divorce rate (correlation coefficient $(-0.67)$; $\mathrm{e}=$ natural growth rate and degree of female dominance over males $(-0,80) ; \mathrm{f}=$ natural growth rate and the mean age at first marriage $(-0,41)$.

There is some connection, but not a close one, between natural growth rate and the proportion of rural population by regions, which indicates that in regions with a larger proportion of rural population, its gender and age structure has been better balanced, which in turn, contributes to greater natural growth. Similarly, correlation analysis confirms a negative impact of the divorce rate on the natural population growth and a somewhat less distinct relationship between natural decrease and increase in the age at first marriage. Therefore, particularly noteworthy in this regard is the relationship of all negative demographic trends. As Terets, V.M. (2009) emphasises, in a truly demographic sense, the ageing population of Ukraine will slow down the process of putting an end to depopulation, firmly maintaining the vicious cycle of "low birth rate - ageing - depopulation". At the same time, correlation analysis did not reveal a dependence of natural growth by regions on GRP per capita and the official unemployment rate.

Stepwise multiple regression analysis was used to produce a statistical model which, through the inclusion of three variables (mean age of the total population, number of full-time students per thousand people, proportion of rural population), explains 97.2 
percent $\left(R^{2}=0.972\right)$ of the dispersion of natural increase. The formula for calculating the natural increase $(N I)$ of administrative units of the highest level in Ukraine is:

$N I=50.486-1.491 M A+0.108 S P+0.040 P R P$,

where $M A$ is the mean age of the total population (years), SP is the proportion of fulltime students (per 10,000 people), PRP is the proportion of the rural population (\%) in the administrative unit. The average deviation of natural increase values, calculated on the basis of the obtained formula from the real values, was -0.4 per thousand (Figure 6).

The role of mean age of the population in natural increase is obvious both in view of the increased proportion of young people of childbearing age and the smaller proportion of elderly people, which reduces mortality (obviously, an inverse effect is also traced here: higher growth reduces the mean age of the total population). As for the proportion of full-time students in higher education institutions, it may be interpreted as a complex indicator that is also related to the higher proportion of young people on the one hand, and to the level of material wellbeing, which significantly correlates with both birth and death rates, on the other hand. The inclusion of the proportion of the rural

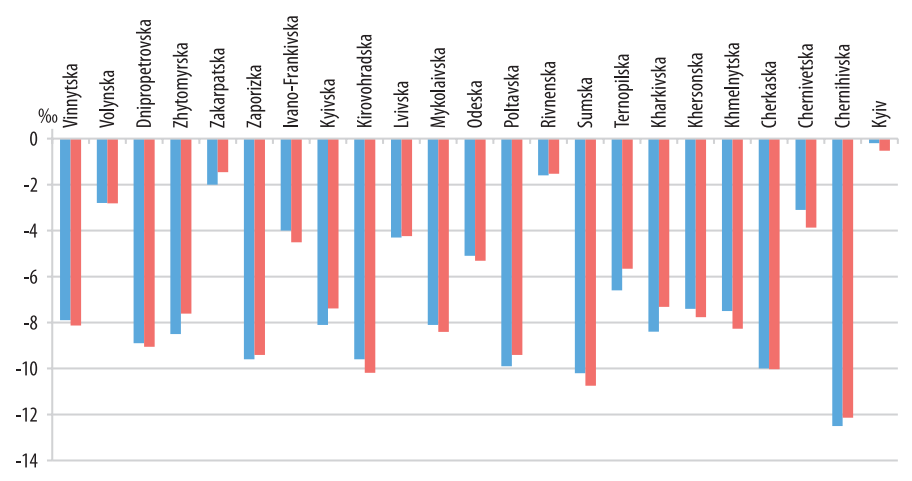

Fig. 6. Natural population growth in the regions of Ukraine (\%o, year 2019) according to the State Statistics Service of Ukraine 2021 (in blue), and the multi-regression model (in red). population in the formula is explained by the increased indicators of the total birth rate in rural areas, especially in the Rivne, Volyn and Chernivtsi regions.

The identified socio-demographic interdependencies objectively reveal and explain other modern regional-demographic differences, some of which appeared in the late $20^{\text {th }}$-early $21^{\text {st }}$ centuries (Dzhaman, V.O. 1998). Thus, the relatively high proportion of people in the younger age categories and the capital's lowest mortality rate in Ukraine (see Figure 3) due to better medical care, determine generally the lowest level of natural population decline in Kyiv (see Figure 4). The demographic preconditions in the regions of Western Ukraine have also remained quite favourable, which is attributed to the social and age characteristics of the population. For instance, in some administrative districts of Volyn, Rivne, Ivano-Frankivsk and Chernivtsi regions a positive natural increase is maintained. However, most districts of Ternopil region have already entered the phase of more intensive depopulation (natural reduction here ranges from $-5.0 \%$ o to $-10.0 \%$ ) (see Figure 4). Similarly, marriage rates are traditionally higher in western Ukraine whereas divorce rates are lower, due to some religious and cultural characteristics and a significant proportion of a more conservative rural population.

The negative consequences of the natural population decline in Ukraine are especially noticeable in rural areas, leading not only to a decrease in the average population of settlements, but also to their gradual disappearance, especially in the Chernihiv, Sumy, Poltava, Kyiv, Zhytomyr and Kirovohrad regions (Figure 7). Thus, during 1991 and 2016, 460 villages were struck from the state register. Further, there were no more permanent resi- 


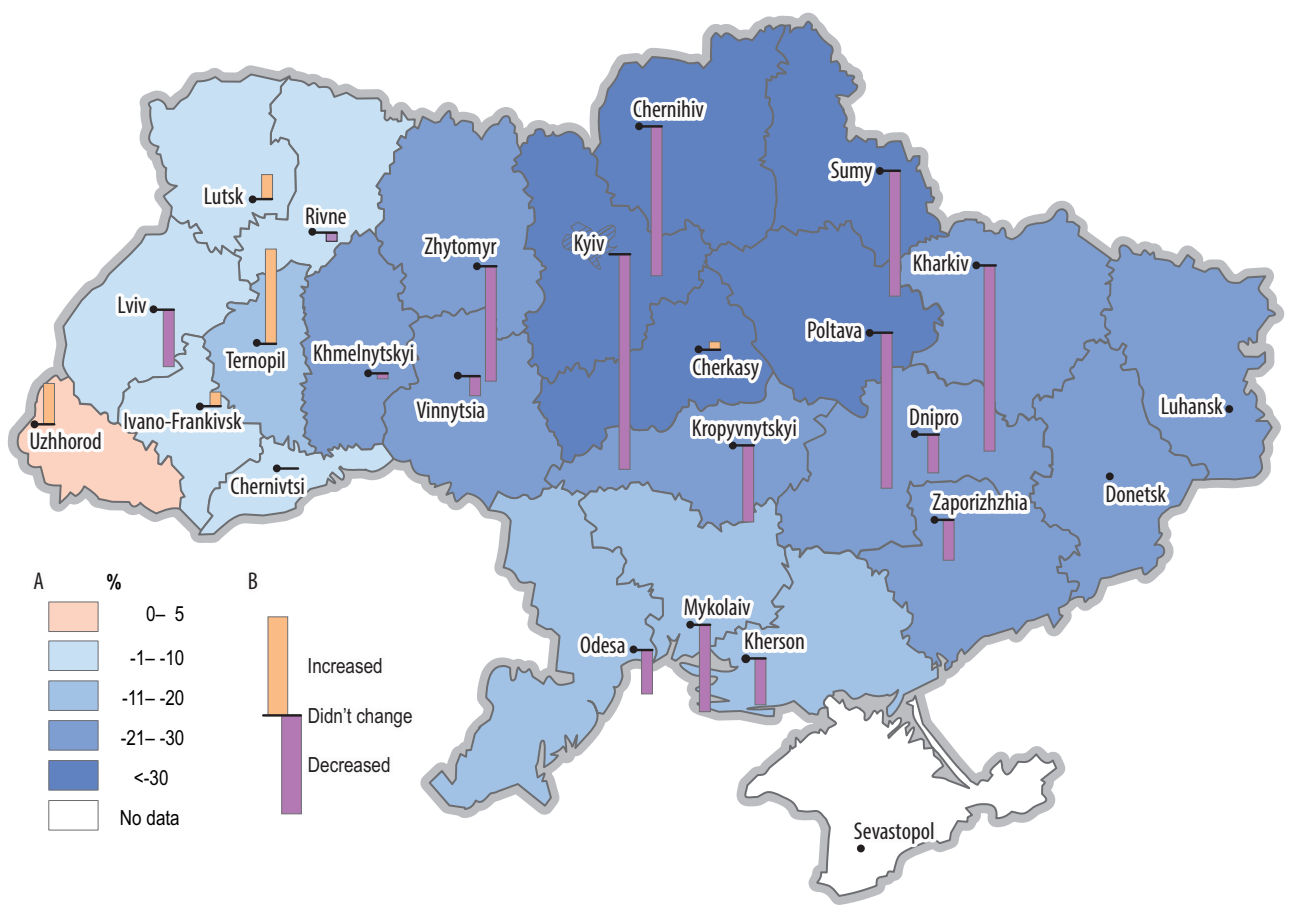

Fig. 7. Change in the number of rural population and rural settlements in the period 1991-2019. - A = The part of rural population increase (decrease) as a result of natural increase (decrease) relative to 1991, in percent. $\mathrm{B}=$ Change in the number of villages ( $1 \mathrm{~mm}$ represents 2 villages).

dents in several hundred other settlements. In addition, in 35 percent of villages in the Sumy region, and in 32 percent of villages in the Chernihiv region not one child was born during 2011 and 2013 (CHAIKA, I.M. 2018). Given the particularly critical situation in the rural areas of the northern districts of Kyiv, Chernihiv and Sumy regions, where the natural population growth is lower $(-20 \%)$ and rural depopulation has been particularly intense, this territory may be defined as a special area of demographic disaster.

The processes of population reproduction were indirectly influenced and have been influenced by various cultural, attitudinal and ethnic factors. In particular, a higher level of religiosity in the western regions which, according to sociological research, amounts to 81 percent, and is, thus, much higher than in the central $(70 \%)$, eastern $(53 \%)$ and southern
(52\%) regions (Razumkov Centre, 2020), resulted in a much smaller number of divorces, and indirectly (due to significantly less abortions) has contributed to rising birth rates.

The ethnic structure of the population is to some extent an additional factor for differentiating regional demographic development. The analysis of the ethnic factor has been complicated by the lack of official statistics of the components of natural increase in terms of nationalities. Therefore, we must limit ourselves to indirect indicators. Thus, because of immigration, more than 200,000 Crimean Tatars arrived in the Crimea between 1989 and 2001. They were characterised by a much higher birth rate, as evidenced by the fact that the mean age of the Crimean Tatars at the time of the 2001 census was 33.4 years, which was significantly lower than the mean age of ethnic Ukrainians (38.2 
years) and ethnic Russians (41.9 years). The slightly lower average age of Ukrainians compared to Russians indirectly indicates higher values of natural increase in their environment, which has some impact on natural growth rates in the regions with the highest share of Ukrainians, especially in the West. Similarly, according to the 2001 census, the demographic indicators of the Romanian ethnic group were more favourable than the average in Ukraine (mean age 35 years, proportion of the population of retirement age 19.3\%) (State Statistics Service of Ukraine 2004), which also affected the reproduction processes in some districts of the Chernivtsi and Zakarpattya regions. However, over the past two decades, there has been a decline in the birth rate of this ethnic group, as evidenced by the current indicators in areas of their mass settlement (see Figure 2).

The situation is somewhat different with the Transcarpathian Hungarians, whose reproductive activity has been lagging behind the indicators of Transcarpathian Ukrainians for decades (on average, the birth rate is lower by 2-3\% - Molnár, J. and Molnár, D.I. 2017). The high natural growth of the Gypsy (Roma) population is well known: it is estimated that the number of births per thousand people among them in the Eastern European region is close to 30 (Molnár, J. et al. 2016; TAYLOR, A. et al. 2018). This affects primarily the reduction of depopulation of the regions of their mass population, especially the Transcarpathia and Odessa regions. In the south-west of the Odessa region, in Budzhak, there are also large numbers Bulgarians, Moldovans and Gagauz. Demographically, they are characterised by a slightly higher birth rate relative to all-Ukrainian indicators (GANCHEV, O.I. 2020), but the rate does not stand out against the background of the local Ukrainian and Russian populations.

Differences in mortality rates among the ethnic groups are less noticeable and are related primarily to the age structure: within the young Roma population it varies between 5-10 per thousand, among Romanians it is about 11 per thousand, and among oth- ers it reaches 13-16 per thousand (MolnaR, J. 2013). Thus, the difference in the natural population growth of nationalities is determined primarily by the birth rate.

Is it realistic to halt the processes of population decline in Ukraine?

The development of demographic processes in Ukraine today is extremely detrimental. Moreover, the negative trends may deepen in the Covid-19 pandemic, leading directly and indirectly not only to higher mortality rates but also to a significant reduction in the number of births and marriages. Since stable mechanisms underlying reproduction of various negative demographic phenomena have already been formed, there is no reason to hope for a large-scale and rapid improvement in the demographic situation. We can only talk about mitigating depopulation trends by means of demographic and socio-economic policies, which should not be limited to individual steps, such as financial assistance in case of childbirth, but should have a comprehensive and regionally differentiated nature. Such a policy is possible based on the implementation of interrelated activities of governmental institutions and civil society organisations, which would provide a system of effective measures in various fields (economic, social, informational, cultural, political). However, in this case it is necessary to determine the actual possibilities, taking into consideration the objective realities and the contradictions of the demographic transition. In this context, it is important to identify those parameters in the demographic situation which may actually be influenced to varying degrees. Thus, it is almost impossible to revive the traditions of a large family, given the current trends in the demographic development of developed countries. Nevertheless, the provision of social guarantees and a relevant information policy makes it possible to gradually move away from the "one family - one child" model and ensure a transition to the national 
average, to simple reproduction (one family - two children). This feasible policy complies with the social and cultural orientations of modern Ukrainian society. Similarly, some other demographic indicators may also be improved by means of a targeted public policy approach. Thus, in particular, it is possible - through social advertising and using information technology - to promote family values. Another step forward, according to European practice, may be the development and practical implementation of programs to support young families and provide them with housing and employment in the related field, which would reduce divorce rates and the average age of men and women at first marriage, as well as indirectly contribute to the growth of birth rate. Additionally, better health care may reduce child mortality, and an effective implementation of life safety systems may reduce unnatural death cases resulting from man-made disasters and traffic accidents. Such measures are obviously unable to balance the gender and age structure of the population in the near future, but they could initiate some trends, the positive consequences of which would become noticeable in the future.

The greatest beneficial effect for finding a delicate demographic balance would be the creation of better socioeconomic conditions to ensure reproductive processes in general. This primarily concerns a significant breakthrough in creation of new jobs, which will reduce labour migration abroad. The latter is currently the major factor causing a negative impact on the demographic situation since permanent residence abroad disrupts family life. Since Ukraine is significantly dominated by urban population (69.5\%), the need to create jobs in cities is particularly acute, especially given the negative trends of deindustrialisation of recent years. Therefore, only the re-industrialisation of the state combined with the development of small and medium-sized businesses in the service sector is able to provide a basis for the working age population employment, which is essential for enhancing family social relations and improving relations among generations. It is noteworthy that a new industrialisation policy has every reason to limit the emigration of scientists and technicians abroad, as well as the departure of young people for higher education in neighbouring countries, since these factors pose serious threats to human resources in view of the loss of highly qualified personnel.

However, optimising the reproductive processes in rural areas is even more difficult because of significant regional differences, in particular the deep demographic crisis affecting rural regions. This situation will require highlighting certain all-Ukrainian principles of socio-economic policy to improve the demographic situation in the Ukrainian countryside and at the same time it will need regionally differentiated approaches to solve specific problems. At the national level, a necessary prerequisite for improving the demographic situation in rural areas is strengthening the economic base of rural areas, thereby improving the engineering and socio-cultural infrastructure of the Ukrainian countryside. For their implementation, both favourable internal (first of all, significant agro-climatic resources) and external preconditions (growth of world food needs) exist. On the other hand, the state has extremely unfavourable economic conditions. Hence, it is important to set priorities, because at present leading positions among business entities are being occupied by large agricultural holdings, which do not have the interests of the local peasantry in mind. At the same time, the socio-economic rise of rural areas requires the opposite - strengthening farming and cooperation of small agricultural producers, implementing of which is important in the agrarian reform. National and international experience indicates the requirement for functional diversification in rural areas for their successful development to meet the needs in the $21^{\text {st }}$ century: successful villages, along with agricultural function, acquire other functions, such as tourism, or those, located close to large cities - residential (Žoncová, M. 2018). 
Given the existence of remote areas, especially in North-eastern Ukraine, where there are few rural settlements left or where there is a lack of a young population, it is necessary to speak about the rural reconstruction of the countryside rather than its strengthening. The need is to create new settlements in the process of the agrarian reform by encouraging the resettlement of the population from densely populated rural areas or cities. With regard to the aforementioned, Geographer BARANovskyi, M. (2009) has emphasised the need to create resettlement and service support centres in rural depressed areas in order to stop negative demographic trends. Such a necessary and purposeful policy for strengthening the economic foundations of rural areas may be combined with administrative and territorial reforms through the creation of various communal enterprises and the development of roads. Therefore, a high rate of natural population decline is today not only an important social problem, but also a problem of national security, and its solution requires the development of a comprehensive government program and the efforts of central and local authorities and the public in general.

\section{Conclusions}

As a result of our research, the following important conclusions can be drawn:

1) Natural population decline in Ukraine began in the 1970s and 1980s in the rural areas of the north-eastern and central regions of Ukraine and had been determined primarily by the objective trends of demographic transition, the inertia of the demographic losses of the past, as well as subjective factors such as artificially accelerated urbanisation combined with the policy of declaring most villages unpromising and encouraging the young population to move to the eastern regions of the then USSR to raise their economy. Adverse social conditions in rural areas and the purposeful encouragement of mass migration of young people from ru- ral areas to large industrial centres laid the groundwork for the mass ageing of the rural population and a sharp decline in birth rates. The socio-economic crisis of the 1990s deepened the depopulation processes, but it was not the main cause of the demographic crisis.

2) Economic difficulties in Ukraine in the 1990s, having formed a state of social uncertainty in society, contributed to a growing number of divorces, a reduction of the number of marriages, an increase in the marriage age and a deterioration of some other demographic characteristics. All these factors have served to deepen the process of depopulation in Ukraine. Nevertheless, the socio-economic crisis was not the main cause of population decline.

3) Correlation analysis found a relationship between the rates of natural population decline and a number of socio-demographic factors (proportion of the rural population, mean age of the inhabitants, divorce rate and the average age at first marriage). Therefore, today the particularly acute effects of the demographic crisis continue to appear in North-eastern and Central Ukraine, where the disparities in gender, age and the socioage structure of the population are the most noticeable, while a relatively better situation can be observed in the Ukrainian capital Kyiv and in some western regions where the sociodemographic indicators are more balanced. Ongoing and, in some cases, increasing labour migration, which brings instability to family relationships, has been a significant negative prerequisite for demographic development in Ukraine and the other post-Soviet countries.

4) Though religious and ethnic factors contribute to some extent to greater natural growth, especially in the western and southwestern regions, their impact on reproduction processes in Ukraine in general has not been significant. Current trends toward a decrease in the religiosity of the population, which replaced the religious upsurge in the 1990s, and are to a varying degree characteristic of all regions of Ukraine and other post-Soviet states, will further limit the im- 
portance of marital status. As a result, they may also indirectly complicate the demographic situation.

5) In order to stop the natural decline of the population in Ukraine, it is important to provide better preconditions for demoreproductive activity, which would relate to the economic, social, informational and cultural spheres of society. In areas of acute demographic crisis, it is important to raise the issue of rural reconstruction involving a variety of organisational and economic mechanisms.

Acknowledgement: Authors would like to thank István MoLnár D. for providing help in the cartographic solutions.

\section{REFERENCES}

Bański, J. and WesoŁowska, M. 2020. Disappearing villages in Poland - Selected socioeconomic processes and spatial phenomena. European Countryside 12. (2): 221-241.

Baranovskyi, M. 2009. Scientific Principles of Sociogeographical Studies of Rural Depressed Areas in Ukraine. Monograph. Nizhyn, PP Lysenko M.M. (in Ukranian)

Brown, D.L. and Glasgow, N. 2012. Rural ageing in the United States: Trends and contexts. Journal of Rural Studies 28 (4): 422-431.

Champion, T. and Shepherd, J. 2006. Demographic change in rural England. In The Ageing Countryside: The Growing Older Population of Rural England. Eds.: Lowe, P. and Speakman, L., London, Age Concern, 29-50. Available at https://www.researchgate.net/ publication/254246210_Demographic_Change_in_ Rural_England

CHAIKA, I.M. 2018. Regional differences in the process of depopulation of rural areas of Ukraine. In Human geography: scientific traditions and contemporary challenges. Lviv, Ivan Franko National University of Lviv, 144-149. (in Ukranian)

DNISTRIANSKYI, M.S. 2012. Demographic crisis in Ukraine: objective historical and geographical background and subjective geopolitical interpretations. Naukoryy visnyk Volyns'koho natsional'noho universytetu imeni Lesi Ukrayinky. Heohrafichni nauky 9. 76-81. (in Ukranian)

Dzhaman, V.O. 1998. To the problem of territorial features of demographic processes in Ukraine. Ukrayins'kyy heohrafichnyy zhurnal / Ukrainian Geographical Journal 3. 13-18. (in Ukranian)
Ganchev, O.I. 2020. Demographic Transformations of the Bulgarian Community of Southern Bessarabia $\left(19^{\text {th }}-\right.$ early $21^{\text {st }}$ century). Odessa, Simeks-Print. (in Ukranian)

Gladun, O.M. 2013. Estimation of hypothetical losses of the population of Ukraine for the period 1897-2012. Demohrafiya ta sotsial'na ekonomika 2. (20): 147-155. (in Ukranian)

Hudzelyak, I.I. 2011. The impact of demographic policy on fertility processes in Ukraine. Visnyk L'vivs'koho universytetu. Seriya heohrafichna 39. 122-130. (in Ukranian)

Karácsonyi, D., Kocsis, K., Kovály, K., Molnár, J. and Póti, L. 2014. East-West dichotomy and political conflict in Ukraine - Was Huntington right? Hungarian Geographical Bulletin 63. (2): 99-134.

KovpaK, L.V. 2010. Unpromising villages. In Entsyklopediya Istoriyi Ukrayiny u 10 t. Vol. 7. Kyiv, Naukova dumka, 372. (in Ukranian)

Kulcsár, L.J. 2019. The demography of rural America. Paper presented at A House Divided: Geographic Disparities in $21^{\text {st }}$ Century America conference. Boston, 4-5 October 2019, 1-23.

Levashov, V.I. and Staroverov, V.I. 2000. Demography and Demographic Development of Russia: a Demostatistical Analysis. Moscow, Rossiyskaya Akademiya Gosudarstvennoy Sluzhby pri Prezidente Rossiyskoy Federatsii. (in Russian)

LevchuK, N.M., Boryak, T.H. and Volovyna, O. 2015. Urban and rural population losses in Ukraine as a result of the Holodomor in 1932-1934: new estimates. Ukrayins'kyy istorychnyy zhurnal 4. 84-112. (in Ukranian)

Libanova, E.M. 2014. Demographic shifts in the context of social development. Demohrafiya ta sotsial'na ekonomika 1.9-23. (in Russian)

MeLnYK, I. 2012. Depopulation in Ukraine: national specifics and regional features. Chasopys sotsial'noekonomichnoyi heohrafiyi 2. 61-65. (in Ukranian)

Molnar, J. 2013. Mortality of the population of the Transcarpathian region in recent years. In Geographical science and practice: challenges of the era. Proceedings of the international scientific conference dedicated to the $130^{\text {th }}$ anniversary of geography at Lviv University. Vol. I. Lviv, Publishing Center of Ivan Franko National University of Lviv, 253-257. (in Ukranian)

Molnár, J., Csernicskó, I. and Braun, L. 2016. Cigányok Kárpátalján (Gypsies in Transcarpathia). In Roma népesség Magyarország északkeleti határtérségében. Eds.: Szilágyi, F. and Pénzes, J., Oradea/ Nagyvárad, Romania, Partium Kiadó, 91-108.

Molnár, J. and Molnár, D.I. 2017. A születésszámok alakulása Kárpátalján térben és időben (Changes in the number of births in Transcarpathia in time and space). In Magyarok a Kárpát-medencében. 2. Tudományos Nemzetközi Konferencia. Ed.: SzónOKYnÉ Ancsin, G., Szeged, Egyesület Közép-Európa Kutatására, 395-409. 
Poruchynska, I. 2014. Comparative analysis of the demographic situation in Volyn Oblast and Lublin Voivodeship. Naukovyy ohlyad 7. 105-113. (in Ukranian)

Razumkov Centre 2020. Religion and the church in the Ukrainian society. Available at https://razumkov.org. ua/uploads/socio/kharkiv_2020.pdf (in Ukranian)

Roнozhin, O.H. 2004. Demographic Prospects of the Ukrainian Village: Historical Preconditions, Regional Analysis and Modelling. Kyiv, Instytut problem natsional'noyi bezpeky i modelyuvannya. (in Ukranian)

RowLAND, R.H. 2004. National and regional population trends in Ukraine: Results from the most recent census. Eurasian Geography and Economics 45. (7): 491-514.

Sehida, K. 2009. Preconditions and factors of demographic development of the regional sociogeosystem. Chasopys sotsial'no-ekonomichnoyi heohrafiyi 2. 185-191. (in Ukranian)

SHvydKa, H.Y. and SHevchuк, P.Y. 2009. Regularities of sex-age structure formation of the population in Ukraine. Demohrafiya ta sotsial'na ekonomika 2. 39-47. (in Ukranian)

SKryZhevska, Y. and Karácsonyi, D. 2012. Rural population in Ukraine: assessing reality, looking for revitalization. Hungarian Geographical Bulletin 61. (1): 49-78.

State Statistics Service of Ukraine 2004. Distribution of the population of the most numerous nationalities by sex and age, marital status, language characteristics and level of education. According to the 2001 Ukrainian Population Census. Kyiv, Derzhavna sluzhba statystyky Ukrayiny. (in Ukranian)

State Statistics Service of Ukraine 2021. Demographic Yearbook "Population of Ukraine" for 2020. Kyiv, Derzhavna sluzhba statystyky Ukrayiny. (in Ukranian)

Stockdale, A. 2011. A review of demographic ageing in the UK: Opportunities for rural research. Population Space and Place 17. (3): 204-221.
TAYlor, A., TÁtraI, P. and ERőss, Á. 2018. Visible minorities in remote areas: a comparative study of Roma in Hungary and Indigenous people in Australia. Hungarian Geographical Bulletin 67. (1): 43-60.

Terets, V.M. 2009. Depopulation and aging of the population in the socio-economic context. Visnyk Khmel'nyts'koho natsional'noho universytetu 1. 92-97. (in Ukranian)

The national economy of the Ukrainian SSR in 1990, 1991. Kyiv, Tekhnika. (in Ukranian)

The population of USSR 1988. Statistical yearbook 1989. Moscow, Statistika i finansy. (in Russian)

YAvorska, V.V. 2015. Analysis of age structural deformations of the population: regional aspect. Naukovyy visnyk Khersons'koho derzhavnoho universytetu. Seriya: Heohrafichni nauky 2. 37-45. (in Ukranian)

Yeliseyeva, L. 2015. Socio-economic challenges of population aging for the national economy. Ekonomichnyy chasopys Skhidnoyevropeys'koho natsional'noho universytetu imeni Lesi Ukrayinky 4. 15-21. (in Ukranian)

VAN DE KAA, D.J. 2002. The idea of a second demographic transition in industrialized countries. Paper presented at the Sixth Welfare Policy Seminar of the National Institute of Population and Social Security, Tokyo, Japan, 29 January 2002, 1-34.

VishnevskiI, A.G. 2005. Demographic Revolution. Moscow, Nauka. (in Russian)

Žoncová, M. 2018. Evaluation of the diversification of rural landscape in Slovakia after 1989 with a focus on the built-up area of municipalities: a case study of Podhájska municipality. Hungarian Geographical Bulletin 67. (1): 143-158.

www.slovoidilo.ua 2019. How many Ukrainians went to work abroad in the last four years. Retrieved from https://www.slovoidilo.ua/2019/01/11/infografika/ suspilstvo/skilky-ukrayincziv-vyyixalo-zarobitkykordon-ostanni-chotyry-roky (in Ukranian) 